\title{
Effects of inducers of systemic acquired resistance on reproduction of root knot nematodes in tomato
}

Muhammad Fiaz ${ }^{1}$, Muhammad Waris ${ }^{2 *}$, Saeed Ahmed ${ }^{3}$, Muhammad Mohsin ${ }^{4}$, Muhammad Ather ${ }^{2}$ and Muhammad Azhar ${ }^{3}$

1. Department of Plant Pathology, University of Agriculture, Faisalabad-Pakistan

2. Department of Plant Pathology Balochistan Agriculture College Quetta-Pakistan

3. Balochistan Agriculture College Quetta-Pakistan

4. Sindh Agriculture University Tando Jam-Pakistan

*Corresponding author's email: waris.faqir@gmail.com

Citation

Muhammad Fiaz, Muhammad Waris, Saeed Ahmed, Muhammad Mohsin, Muhammad Ather and Muhammad Azhar. Effects of inducers of systemic acquired resistance on reproduction of root knot nematodes in tomato. Pure and Applied Biology. Vol. 7, Issue 3, pp1131-1136. http://dx.doi.org/10.19045/bspab.2018.700132

\begin{tabular}{llll}
\hline \hline Received: 27/04/2018 & Revised: 28/07/2018 & Accepted: 02/08/2018 & Online First: 06/08/2018
\end{tabular}

\section{Abstract}

Root knot nematodes (Meloidogyne specie) are major threat for vegetable crop production in Pakistan. The experiments of inducers (Salicylic Acid, Jasmonic Acid and Benzoic Acid) as seedling dip treatment was designed and Systemic Acquired Resistance (SAR) developed in Money maker Variety of tomato and the efficiency of most effective concentration of inducers on the invasion and development of root knot nematode was determined. First experiment was on the effect of inducers (Salicylic Acid, Jasmonic Acid and Benzoic Acid) on nematode reproduction and their influence as induction of (SAR) on plant growth and development of root knot nematodes on host plant under controlled conditions. Second experiment on development of Juvenile2 (J2) in roots of Money maker Variety of tomato growing in the presence of inducers was run under natural conditions. At harvest of field; data of population of $\mathrm{J} 2$ penetration and development, final $\mathrm{J} 2$ population in roots and soil, galling index, number of females/ 1 gm of soil, root galling and egg masses was assessed on 0-5 scale. Salicylic Acid and Jasmonic Acid @ 7mg/mL and 10mg/mL showed significant control of root knot nematodes as compared to Benzoic Acid. Most effective inducers were selected to investigate its role for the management of root knot nematodes associated with tomato. It is concluded that comparison of treatment means regarding to Analysis of Variance (ANOVA) indicated that Jasmonic Acid @ 10mg/mL showed more significant results for reduction of root knot nematodes in both experiments.

Keywords: Inducers; Root knot nematodes; Systemic acquired resistance; Tomato

\section{Introduction}

Tomato (Lycopersicon esculentum Mill.) is an important vegetable crop that is cultivated in the world as well as in Pakistan. Due to high nutritional value and medicinal importance; it plays a pivotal role to the dietary intake of vitamins A, C, crucial mineral and nutrients as well as lycopene, a chief component of red tomatoes with an antioxidant property which diminishes cancers. It is approximately grown in every corner of the planet. It is the second most 
important vegetable crop in the world in terms of consumption per capita. It belongs to family Solanaceae $[1,2]$. On global basis, Tomato is planted on 4.6 million hectares with a total production of 150 million metric tonns [3]. In Pakistan, tomatoes are being cultivated over an area of about 53.1 thousand hectares with mean yield of 10.1 tons $\mathrm{ha}^{-1}$ and total production 476900 tones [4]. Among various obstructions of low yield different diseases caused by bacterial, fungal, viral and nematode pathogens. Among nematode pathogens Meloidogyne spp is prevalent and familiar as a damaging pathogen of tomato $[5,6]$. Due to root knot nematodes yield losses range from $20 \%$ to $33 \%$ [7]. Tomato is frequently damaged by root-knot nematodes, Yield losses from 35$39.7 \%$ have been reported due to nematode attack [8]. Meloidogyne spp. is a dread to both commercial and small holder producers occupied in intensive tomato cultivation and it is a chief pest of tomato and its rescue infestations can exterminate a whole tomato plant [9].

Application of cultural practices such as (rotation, fallow, soil solarization, tolerant varieties, etc.) decrease nematode populations. Plant inducers like Jasmonic acid (JA), Salicylic acid (SA) and Acetylsalicylic acid (ASA) have been established to be active as antimicrobial agents in various trials as disease resistance inducers. Above mentioned inducers have been described for inducing resistance against several disease causing agents. i.e. bacterial wilt bacterial soft rot [10]. As well as wilt diseases [11]. And Soil borne fungal root rot [12]. In addition to fungal foliar diseases [13]. Keeping in view the importance of inducers of SAR present studies have been planned with the following objectives.

To managed root knot nematodes by drenching tomato seedling with available plant inducers at different concentrations in field and pot trial and to minimized nematode attack by inducing systemic acquired resistance through exogenous application of plant inducers.

\section{Materials and methods}

A field experiment was conducted at the Experimental Research Area in a randomized block design on infested field plot of $125 \mathrm{~m}^{2}$ size. Recommended application of fertilizer (25:50:25 NPK kg/ha) was applied a day before transplanting Money maker variety of tomato and Tomato was transplanted with inter- and intra-row spacing of 50 and $30 \mathrm{~cm}$ respectively. Thirty day-old seedlings of tomato (money maker) was drenching on (1 $\mathrm{mL} /$ seedling) with 3 rates from stock solutions (5.0, 7.0 and $10.0 \mu \mathrm{g} / \mathrm{mL}^{-1}$ ) of Salicylic acid (SA), Jasmonic acid (JA) and Benzoic acid (BA) for 12 hours. Each treatment was replicated three times and an untreated plant was kept to serve as control. The plot was flood irrigated $(5 \mathrm{~cm})$ at intervals of 20 days. The weeds from the plot were subsequently removed manually. Data on yields was recorded based on maturity and nematodes development parameters like number of females, number of galls per gram, number of nematodes $/ 100 \mathrm{ml}$ of soil and egg masses was recorded on harvest.

Five thousand $\mathrm{J}_{2}$ of female Meloidogyne spp in $10 \mathrm{ml}$ was inoculated around the base of each pot for infestation. Treated nursery was transplanted in $1.5 \mathrm{~L}$ earthen pots containing formalin sterilized sandy loam soil. The Pots experiment was arranged in Complete Randomized Design (CRD) with three replications of each treatment. Untreated plant served as control. Tomato plants were watered daily and fertilized as needed. Data was recorded after 7, 14, 21, 28 an d 35 days after maturity and nematodes development parameters like number of females, number of galls per gram, number of nematodes $/ 100$ $\mathrm{ml}$ of soil and egg masses were recorded on harvest. 


\section{Results and discussion}

Pot experiment showed that application of inducers at concentrations of 5.0, 7.0 and $10.0 \mathrm{mg} / \mathrm{mL}^{-1}$ respectively by adding SA, JA and BA and significantly $(\mathrm{p} \leq 0.05)$ reduced nematode reproductive parameters like number of females, egg-masses, galls and juveniles /pot, respectively compared to whole plants inoculated by root knot

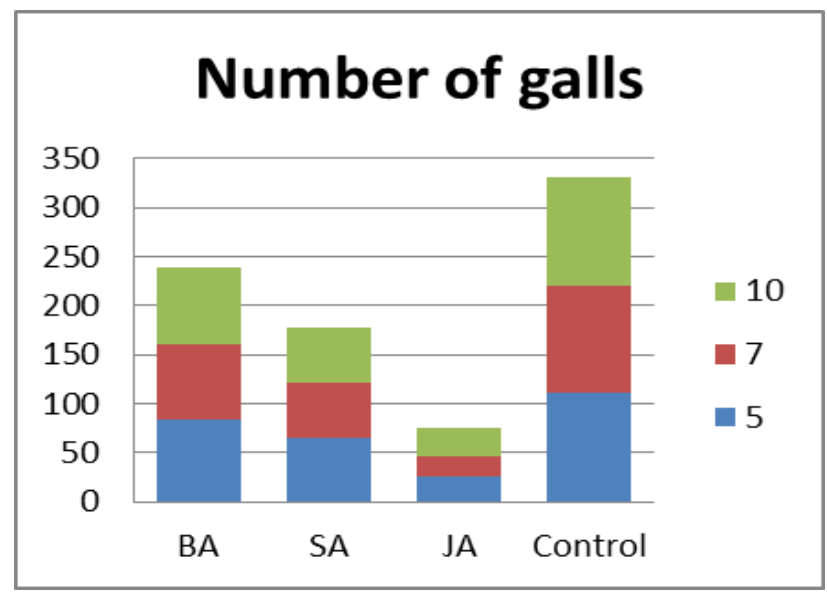

Figure 1. Effect of inducers on number of galls

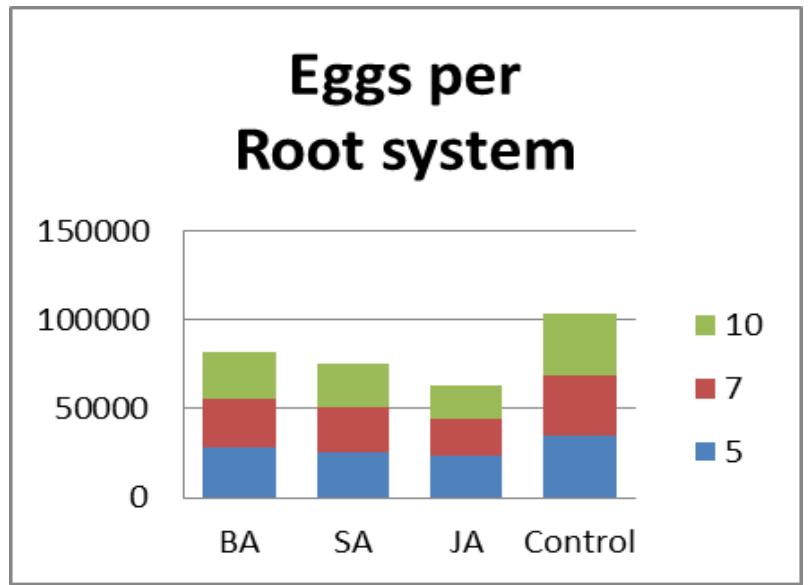

Figure 3. Effect of inducers on egg per root system

Field experiment observed that application of inducers at concentrations of 5.0, 7.0 and $10.0 \mathrm{mg} / \mathrm{mL}^{-1}$ respectively by adding $\mathrm{SA}$, $\mathrm{JA}$ and $\mathrm{BA}$ and significantly $(\mathrm{p} \leq 0.05)$ reduced nematode reproductive parameters like number of females, egg-masses, galls nematodes only. All inducers showed the reasonable reduction of nematode reproduction but Jasmonic acid showed best results as compared to Salicylic acid and Benzoic acid at $10.0 \mathrm{mg} / \mathrm{mL}^{-1}$. Treated plants observed 30-35\% reduction of Root Knot Nematode (RKN) population as compared with untreated plants as given in all four figures (Figures 1, 2, $3 \& 4$ ).

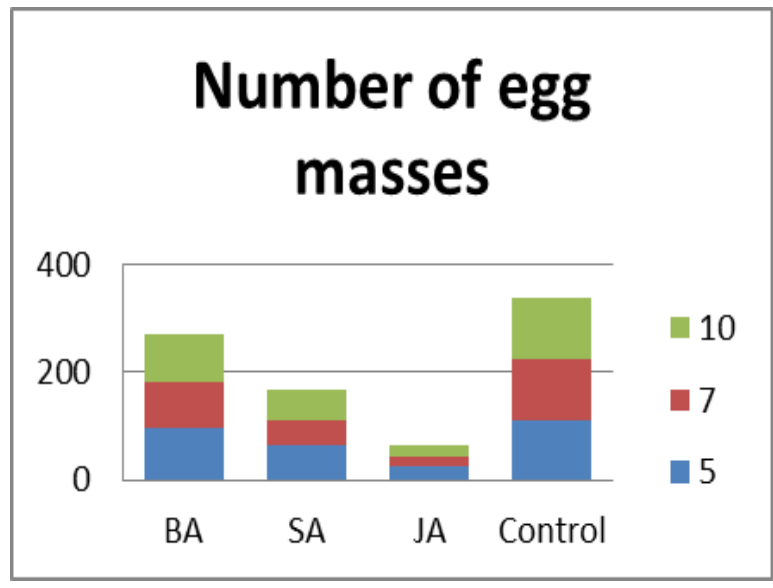

Figure 2. Effect of inducers on number of egg masses

\section{Eggs per gram of root}

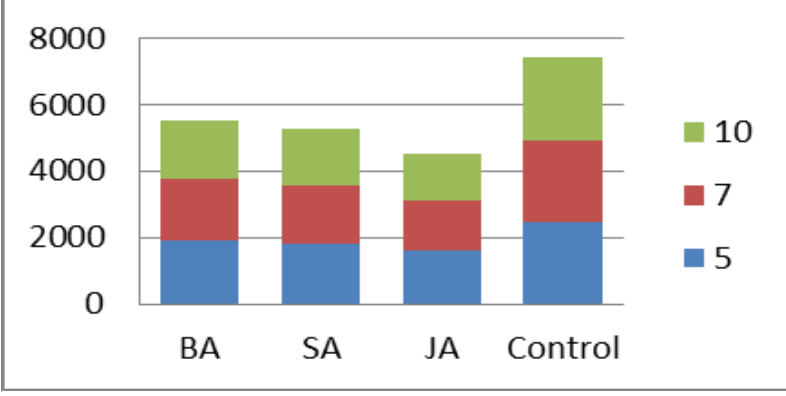

Figure 4. Effect of Inducers on Eggs per gram of root

and juveniles /pot, respectively compared to whole plants inoculated by root knot nematodes only. All inducers showed the reasonable reduction of nematode reproduction but Jasmonic acid showed best results as compared to Salicylic acid and 
Benzoic acid at $10.0 \mathrm{mg} / \mathrm{ml}^{-1}$ as given in (Table 1).

To demonstrate the role of systemic acquired resistance of inducers against root-knot nematode and it's infecting tomato plants. The results showed a reduction occurred in the reproductive parameters of the nematodes and improvement of growth parameters of the plant was observed. These results agree with other investigations. Salicylic acid (SA), Jasmonic Acid (JA) and Benzoic Acid (BA) are known to play a critical signaling role in the activation of plant defense responses after pathogen attack. These inducers are considered as plant defense signal and have induced resistance in several plant species.
Induced resistance has been obtained in numerous plant species with mentioned inducers, by a mechanism including induction of pathogenesis-related protein (PR-protein). Moreover, Inducers have been reported as an endogenous signal for the activation of certain plant defense responses by expression of genes for pathogenesisrelated protein (PR-1) and enhanced resistance to pathogens. Inducers, in particular, have a biotic role in nematode susceptible plants. It has been regarded as resistance inducer in such susceptible plants. The role of SA inside plants has been explained by many workers as given in (Table 1).

Table 1. Effects of chemical inducers (Jasmonic Acid, Salicylic Acid and Benzoic Acid) against root knot nematode development parameters of tomato under natural conditions

\begin{tabular}{|c|c|c|c|c|c|c|c|}
\hline Inducers & $\begin{array}{l}\text { Concentration } \\
(\mathrm{gm} / \mathbf{m L})\end{array}$ & $\begin{array}{l}\text { No. of } \\
\text { galls/root } \\
\text { system }\end{array}$ & $\begin{array}{c}\text { No. of } \\
\text { females/ } \\
\text { root } \\
\text { system }\end{array}$ & $\begin{array}{l}\mathrm{J} 2 / \text { root } \\
\text { system }\end{array}$ & $\begin{array}{c}\mathrm{J} 2 / 100 \mathrm{~cm}^{3} \\
\text { of soil }\end{array}$ & $\begin{array}{l}\text { Egg } \\
\text { mass }\end{array}$ & $\begin{array}{l}\text { Galling } \\
\text { Index }\end{array}$ \\
\hline \multirow{3}{*}{ 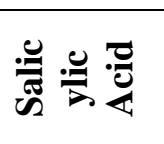 } & 5 & $90 \mathrm{~b}$ & $135 \mathrm{~b}$ & $21745 b$ & $3219 \mathrm{~b}$ & $132 \mathrm{~b}$ & $4 \mathrm{~b}$ \\
\hline & 7 & $81 \mathrm{~b}$ & $127 \mathrm{~b}$ & $21602 b$ & $3145 \mathrm{~b}$ & $124 \mathrm{~b}$ & $4 \mathrm{~b}$ \\
\hline & 10 & $75 \mathrm{~b}$ & $113 \mathrm{~b}$ & $21572 \mathrm{~b}$ & $3025 \mathrm{~b}$ & $109 \mathrm{~b}$ & $4 \mathrm{~b}$ \\
\hline \multirow{3}{*}{ 害哭 } & 5 & $39 \mathrm{c}$ & $42 \mathrm{c}$ & $11912 \mathrm{c}$ & $1017 \mathrm{c}$ & $39 \mathrm{c}$ & $3 \mathrm{c}$ \\
\hline & 7 & $28 \mathrm{c}$ & $37 \quad \mathrm{c}$ & $11834 \mathrm{c}$ & $956 \mathrm{c}$ & $35 \mathrm{c}$ & $3 c$ \\
\hline & 10 & $23 \mathrm{c}$ & 31 c & $11711 \mathrm{c}$ & 877 c & $28 \mathrm{c}$ & $3 \mathrm{c}$ \\
\hline \multirow{3}{*}{ 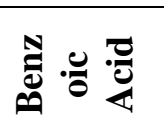 } & 5 & $93 \mathrm{~b}$ & $146 \mathrm{~b}$ & $21808 \mathrm{c}$ & $3543 \mathrm{~b}$ & $144 \mathrm{~b}$ & $4 \mathrm{~b}$ \\
\hline & 7 & $88 \mathrm{~b}$ & $134 \mathrm{~b}$ & $21630 \mathrm{c}$ & $3341 \mathrm{~b}$ & $131 \mathrm{~b}$ & $4 \mathrm{~b}$ \\
\hline & 10 & $79 \mathrm{~b}$ & $109 \mathrm{~b}$ & $21580 \mathrm{c}$ & $3190 \mathrm{~b}$ & $105 \mathrm{~b}$ & $4 \mathrm{~b}$ \\
\hline Control & Water & $165 \mathrm{a}$ & $180 \mathrm{a}$ & $22716 \mathrm{a}$ & $4676 \mathrm{a}$ & $162 \mathrm{a}$ & $5 \mathrm{a}$ \\
\hline LSD & & 12.68 & 15.17 & 13.60 & 9.25 & 11.99 & 12.79 \\
\hline
\end{tabular}

\section{Discussion}

Systemic Acquired Resistance (SAR) inducers differed in their ability to reduce nematode reproduction on tomato. Jasmonic Acid, Benzoic Acid, and Salicylic Acid are among the most potent SAR inducers. Differential potency among SAR inducers and between nematode species may be due to different activation points along the signal transduction pathway of SAR as per results of my research. Among three inducers Salicylic Acid, Jasmonic Acid and Benzoic
Acid tested against Meloidogyne spp. infection variation was observed. This variation of inducers to nematode infection might be related to quality of systemic acquired resistance of the genotype $[14,15]$. And the level of resistance mechanisms possessed by a particular genotype [16]. It is likely that Jasmonic Acid induces components upstream of those triggered by Salicylic Acid and Benzoic Acid in the signal transduction pathway for resistance to rootknot and root knot nematodes. Therefore, 
resistance induced by inducers showed a broader spectrum of control than that activated by Salicylic Acid, Jasmonic Acid and Benzoic Acid. All inducers had ability to reduce no. gall and egg mass indices $>3$ and rate of reproduction $>1$ [17]. It indicates that these inducers had the ability to suppress the reproduction of the adult female. Tomato genotype has varying degrees of susceptibility/resistance to root knot nematode infestation. This may be due to soil type because of variation among fields [18]. The better activities of peroxidase have been pragmatic in SA treated cowpea and this increased peroxidase activity was correlated with the enhanced plant defense against pathogen attack. It is additionally improved the activities of another enzyme catalase, which may be concerned in the induction of plant defence responses in different plant crops and vegetables. This suggests that chemical regulators $\mathrm{SA}$ and $\mathrm{JA}$, may be involved in induction of general defensive compounds in plants against infection by root knot nematodes [19]. These research experiments proved that development of reproduction of root knot nematodes are reduced due to the inducers have a Systemic Acquired Resistance (SAR) mode of action, penetration of root knot nematodes in roots also reduced. In the same way, it is also proved that Jasmonic Acid produced systemic action against reproduction of root knot nematodes, which later was capable to impediment the progress of the plant parasitic nematodes. These experiments interpreted that if these chemical inducers are functional as a defensive management to plants before transplanting of nursery and then later as a restorative behavior, they capacity to supply a enhanced nematode managing approach. To get more information regarding the efficiency of inducers field trials are requisite.

\section{Conclusion}

It is concluded that all inducers showed reduction of Root Knot Nematode reproduction. Jasmonic acid showed best results as compared to Salicylic acid and Benzoic acid at $10.0 \mathrm{mg} / \mathrm{ml}$. Treated plants observed 30-35\% reduction of RKN population as compared with untreated plants and improvement of growth of the plant was observed.

\section{Authors' contributions}

Conceived and designed the experiments: $\mathrm{M}$ Waris, Performed the experiments: M Fiaz \& M Waris, Analyzed the data: M. Waris \& M Mohsin, Contributed materials/ analysis/ tools: S Ahmed, M Ather, M Azhar \& M Mohsin, Wrote the paper: M Fiaz \& M Waris.

\section{Reference}

1. Rick CM (1980). Hybridization of crop plants. Am. Soc. Agron. /Crop Sci Soc Am Madison, WI, USA, pp 669-680.

2. Giovannucci E (1999). Tomatoes, tomato-based products, lycopene and cancer; Rev. Epidemiol Lit J Natl Cancer Inst 91: 317-331.

3. Anonymous (2011). Agriculture Statistics of Pakistan, Govt. of Pakistan, Ministry of Food and Agriculture, Food and Agriculture Division (Economic wing). Islamabad. pp 54-55.

4. Pakistan Bureau of Statistics (2011). Govt. of Pakistan, Ministry of Food, Agric Livest Econ Wing, Islamabad.

5. Fourie H \& McDonald AH (2000). Nematodes ARCLNR Leaflet. $\mathrm{Cr}$ Prot Ser 18: 4-8.

6. Kamran M, Anwar SA, Javed M, Khan SA \& Sahi GH (2010). Incidence of rootknot nematodes on tomato in Sargodha, Punjab, Pakistan. Pak J Nematol 28: 253-262.

7. Sasser JN (1989). Plant parasitic nematode: the farmer hidden enemy. North Carolina State University. USA. pp 13. 
8. Hadad MA \& Hashmi HS (2012). Comparative effects of inoculating tomatoes (Lypersicon esculentum mill.) with two strains of VAM fungi and nematicides application on the control of root-knot nematodes (Melidogyne incognita). CABI Publishing, Wallingford. 3-32.

9. Kamran M, Anwar SA \& Khan SA (2011). Evaluation of tomato genotypes against Meloidogyne incognita infection. Pak J Phytopathol 23: 31-34.

10. Sayed EWM (1996). Induction of resistance to bacterial soft rot disease of potato tubers by application of acetylsalicylic acid (aspirin). Ann Agric Sci Ain Shams Univ 41: 993-1006.

11. Chunquan CS, Belanger RR, Benhamou N, Paulitz TC \& Chen CQ (1999). Role of salicylic acid in systemic resistance induced by Pseudomonas spp. against Pythium aphanidermatumin on cucumber roots. Eur J Pl Pathol 105: 477-486.

12. Mandavia MK, Khan NA, Gajera HP, Andaria JH \& Parameswaram M (2000). Inhibitory effects of phenolic compounds on fungal metabolism in host-pathogen interactions in Fusarium wilt of cumin. Allelopathy J 7: 85-92.

13. Srinivas $T$, Rao $K \&$ Chattopadhayay $C$ (1997). Effect of botanicals and chemicals on the management of blight (Alternaria alternata; Alternaria helianthi) of sunflower (Helianthus annus). Zeitschrift Fur
Pflanzenkrankheiten and Pflanzenschutz. 104: 523-527.

14. Uknes S, Mauch-Mani B, Moyer M, Potter S, Williams S, Dincher S, Chandler D, Slusarenko A, Ward E. \& Ryals J (2004). Acquired resistance in Arabidopsis. Plant Cell 4: 645-656.

15. Van Loon LC, Rep M \& Pieterse CMJ (2006). Significance of inducible defense-related proteins in elected plants. Anпu Rev Phytopathol 44: 135162.

16. Anwar SA \& Mckenry MV (2000). Penetration, development, and reproduction of Meloidogyne arenaria on two new resistant Vitis spp. Nematropica, Pak Int J Nematol 30: 917.

17. Van Wees SCM, Deswart EA, Van Pelt JA, Van-Loon LC \& Pieterse CMJ (2000). Enhancement of induced disease resistance by simultaneous activation of salicylate- and jasmonate-dependant defense pathways in Arabidopsis thaliana. Proc Natl Acad Sci USA 15: 8711-8716.

18. Anwar SA, Zia A, Hussain M \& Kamran M (2007). Host suitability of selected plants to Meloidogyne incognita in the Punjab, Pak Int J Nematol 17: 144-150.

19. Fernandes WC, Ton Flors V, Métraux JP \& Mauch MB (2006) Enhancing Arabidopsis salt drought stress tolerance by chemical priming for its abscisic acid responses. Pl Physiol 94: 117-131. 